\title{
Greenhouse gas emissions and energy efficiencies for soybeans and maize cultivated in different agronomic zones: A case study of Argentina
}

\author{
E.M. Arrieta ${ }^{\text {a,* }}$, A. Cuchietti ${ }^{\text {a }}$, D. Cabrol ${ }^{\text {b }}$, A.D. González ${ }^{\mathrm{c}}$ \\ a Instituto Multidisciplinario de Biología Vegetal (IMBIV), CONICET y Universidad Nacional de Córdoba, 5000 Córdoba, Argentina \\ b Instituto de Humanidades (IDH-CONICET-UNC), Pab. Agustín Tosco, 1er piso - Ciudad Universitaria, 5000 Córdoba, Argentina \\ c Instituto Andino-Patagónico de Tecnologías Biológicas y Geoambientales (IPATEC), CONICET y Universidad Nacional del Comahue, 8400 Bariloche, Río Negro, Argentina
}

\section{H I G H L I G H T S}

- We obtained the carbon and energy footprints of soybean and maize in Argentina.

- Pampean and extra-Pampean regions comprising 1.53 million $\mathrm{km}^{2}$ were analyzed.

- 18 agronomic zones included in two major regions were considered.

- Highest footprints of GHGs and energy found in extra-Pampean region for both crops.

- The mean annual precipitation explains regional differences in efficiencies.

\section{A R T I C L E I N F O}

\section{Article history:}

Received 27 October 2017

Received in revised form 23 December 2017

Accepted 23 December 2017

Available online $\mathrm{xxxx}$

Editor: J Jay Gan

\section{Keywords:}

Carbon footprint

Energy footprint

Efficiencies

Soybean

Maize

Crop production
G R A P H I C A L A B S T R A C T

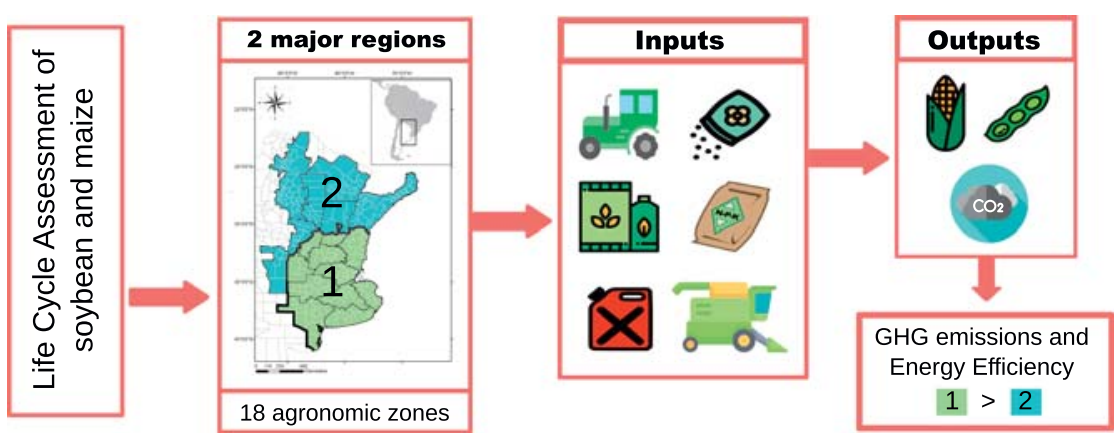

\begin{abstract}
A B S T R A C T
Of all human activities, agriculture has one of the highest environmental impacts, particularly related to Greenhouse Gas (GHG) emissions, energy use and land use change. Soybean and maize are two of the most commercialized agricultural commodities worldwide. Argentina contributes significantly to this trade, being the third major producer of soybeans, the first exporter of soymeal and soybean oil, and the third exporter of maize. Despite the economic importance of these crops and the products derived, there are very few studies regarding GHG emissions, energy use and efficiencies associated to Argentinean soybean and maize production. Therefore, the aim of this work is to determine the carbon and energy footprint, as well as the carbon and energy efficiencies, of soybeans and maize produced in Argentina, by analyzing 18 agronomic zones covering an agricultural area of 1.53 million $\mathrm{km}^{2}$. Our results show that, for both crops, the GHG and energy efficiencies at the Pampean region were significantly higher than those at the extra-Pampean region. The national average for production of soybeans in Argentina results in 6.06 ton/ton $\mathrm{CO}_{2}$-eq emitted to the atmosphere, while 0.887 ton of soybean were produced per $\mathrm{GJ}$ of energy used; and for maize 5.01 ton/ton $\mathrm{CO}_{2}$-eq emitted to the atmosphere and 0.740 ton of maize were produced per each $\mathrm{GJ}$ of energy used. We found that the large differences on yields, GHGs and energy efficiencies between agronomic regions for soybean and maize crop production are mainly driven by climate, particularly mean annual precipitation. This study contributes for the first time to understand the carbon and energy footprint of soybean and maize production throughout several agronomic zones in Argentina. The significant differences found in the productive efficiencies questions on the environmental viability of expanding the agricultural frontier to less suitable lands for crop production.
\end{abstract}

(c) 2017 Published by Elsevier B.V.

\footnotetext{
* Corresponding author.

E-mail address: earrieta@imbiv.unc.edu.ar (E.M. Arrieta).
} 


\section{Introduction}

Worldwide, agriculture emits $24 \%$ of total anthropogenic Greenhouse Gases (GHG), use an important fraction of the energy and occupy $38 \%$ of the Earth's ice free land (Pelletier et al., 2011; Tubiello et al., 2015; FAOSTATS, 2017). Due to population growth, dietary changes and an increased demand for biofuels, agriculture production shall be increased in the next decades, in particular the production of grains (Kastner et al., 2012). This will cause even larger environmental impacts, with associated increases in GHG emissions, energy use and land use change (Godfray and Garnett, 2014). On the other hand, to achieve a global temperature rise lower than $2{ }^{\circ} \mathrm{C}$ above preindustrial levels, the scientific consensus calls for a sharp decreasing of GHG (IPCC, 2007). The agricultural sector has a high potential to mitigate climate change, not only due to reductions in fossil fuels but also on emissions of non- $\mathrm{CO}_{2}$ gases, mainly $\mathrm{N}_{2} \mathrm{O}$ and $\mathrm{CH}_{4}$ emitted in soil cultivation, manufacturing of fertilizers and animal husbandry (Wollenberg et al., 2016).

Maize is the grain with the largest production worldwide, with 960 million tons per year, and soybean is the fourth in quantity with 313 million tons per year (USDA, 2017). Both grains have multiple uses in global markets: directly in food consumption, as additives and supplements, animal feed and primary source for biofuels (Foley et al., 2011; FAO, 2017). The cultivated area for maize has been increased around 66 million hectares (56\%) between 1971 and 2014; while the area for soybeans was expanded in an impressive way: from 30 million hectares to 117 million hectares in the same period of time (FAOSTAT, 2017). These expansions of cultivated area had a large impact in South American countries where a large portion of the increase occurs (Gasparri and Waroux, 2015). In Argentina, the total area for maize cultivation has been quite constant. However, as in the rest of the world, yields have experienced sharp increases, which almost tripled the production in a period of 40 years (Edgerton, 2009). On the contrary, soybean cultivation area in Argentina raised enormously from 36,000 ha in 1971 to 19 million in 2014, and at present with nearly $100 \%$ genetically modified varieties cultivated using no-till farming and in monoculture practices in several cases. The so-called "soybean package" has been extensively adopted for its effectiveness (Trigo et al., 2009). The sharp increase in soybean cultivation based on large demand of inputs and technology has been one of the main drivers for the expansion of the agricultural frontier in Argentina and South America during the last decades (Zak et al., 2008; De Sy et al., 2015; Fehlenberg et al., 2017).

In 2016, the cultivation area for grains in Argentina was 39 million hectares, of which $52 \%$ was dedicated to soybean and $17 \%$ to maize, leading to a production of 58.7 and 39.7 million tons respectively (IAIS, 2017). Worldwide, Argentina is the third major producer of soybeans but the first exporter of soymeal and soy oil, accounting for 30.3 and 5.7 million tons exported respectively (USDA, 2017). Besides the production of maize in Argentina represents only 4\% of the total globally, the country is the third major exporter (USDA, 2017).

The cultivation of both grains is highly dependent on fertilizers, fuels, machinery and pesticides, which contributes to GHG emissions and energy resource use, two relevant environmental-impact indicators related to agricultural practices. A way to assess their contribution to different production systems consists in estimating the carbon and energy footprint of agricultural products by quantifying the GHG emissions and energy inputs required to produce a given amount of food (Pelletier et al., 2011). Thus, GHGs and energy footprints are defined here as the amount of GHGs emitted or energy used per unit of weight of grain obtained. In the same line, other useful indicators are carbon and energy efficiencies, which are defined as the amount of food produced per unit of GHGs emitted and energy used (Clark and Tilman, 2017). The efficiencies, therefore, account for the production obtained per unit of burden released or resource depleted.

Even though the leading participation of Argentina in the production of grain and their by-product markets, only few studies have attempt to assess the use of energy and GHG emissions of the country's maize and soybeans productions (Dalgaard et al., 2008; Panichelli et al., 2009; Castanheira and Freire, 2013). However, these studies were based on national averages obtained from public databases without including regional variations, which in Argentina are very important due to territorial extension and large ecological variability. On the other hand, as we will discuss in the present work, exploring regional variations lead to understand the convenience or not to expand the agricultural frontier into regions with no favorable conditions for crop production.

Therefore, the aim of the present study is to investigate the carbon and energy footprint of soybean and maize, as well as the carbon and energy efficiencies, by analyzing the production of both crops through different agronomic zones in Argentina, which represents $>98 \%$ of the soybean and maize production of the country. Variability in efficiencies across different zones due to climate conditions may be relevant not only to assess environmental impacts but also to study the policy implications and potentials for improvements.

\section{Materials and methods}

\subsection{System boundaries}

The present study is limited to the production of soybean and maize delivered at farm gate. The carbon and energy footprints were obtained per ton of grain. All stages in the cultivation process, as preparation of the soil, fertilization, sowing, biological soil emissions, harvest and emissions of residues left on the field have been included. The energy and GHG emissions of all agricultural inputs were obtained and included in the impacts. Farm equipment production and human labor were not included in the system boundary due to their small contribution to the overall impact. In Argentina the most common procedure is contracting a service to make the farming labor, which diminish equipment idling and hence the influence of equipment burdens on per hectare based. According to the Argentine Federation of Agricultural Machinery Contractors, rural contractors' participation is $60 \%$ for sow, $75 \%$ for pesticide applications and $90 \%$ of harvest, this last one with the most complex and costly machinery. Therefore, in this case the GHG and energy allocation procedure have to be made taking into account that the equipment has very low idling time. Using data of Mikkola and Ahokas (2010) we found that the GHG emissions and energy embodied in the manufacture, transport from plant to farm and repair, and service and maintenance of farming machinery, is $<0.5 \%$ of the overall results, accounting for $196 \mathrm{MJ} / \mathrm{ha} / \mathrm{año}$ (see Table 5 of Appendix A for more details). Infrastructure (e.g., road, rail, etc.) is also excluded in the analysis due to lack of reliable data. Rainfed agriculture is the prevalent practice in crop production in Argentina, thus irrigation considered in this study. Viglizzo et al. (2011) reported that irrigated land in Argentina represents $<0.5 \%$ of the country surface, mostly located outside our study area and dedicated to wine and olive production.

\subsection{Study area}

The study extended over approximately 1.53 million $\mathrm{km}^{2}$ (55\% of Argentina's continental area) and it comprises 258 administrative districts divided into 18 agronomic zones, covering all the Argentinian Chaco-Pampean plain (Fig. 1). This area comprises $89 \%$ of human population, $98 \%$ of bovine cattle heads and over $90 \%$ of annual and perennial crops of the country. Dominant biomes in the area are grasslands; tropical, subtropical and temperate forests and shrub lands; with many areas being replaced by croplands (Viglizzo et al., 2011). Agricultural exports from this area include soybean, sunflower, maize, wheat and beef. The agronomic zones were obtained from the Department of Agricultural Estimates of the Buenos Aires Grain Exchange (BAGE, 2017). This geographical zoning is based on homogeneous agronomic criteria, including type of soil, climate and rain patterns. 


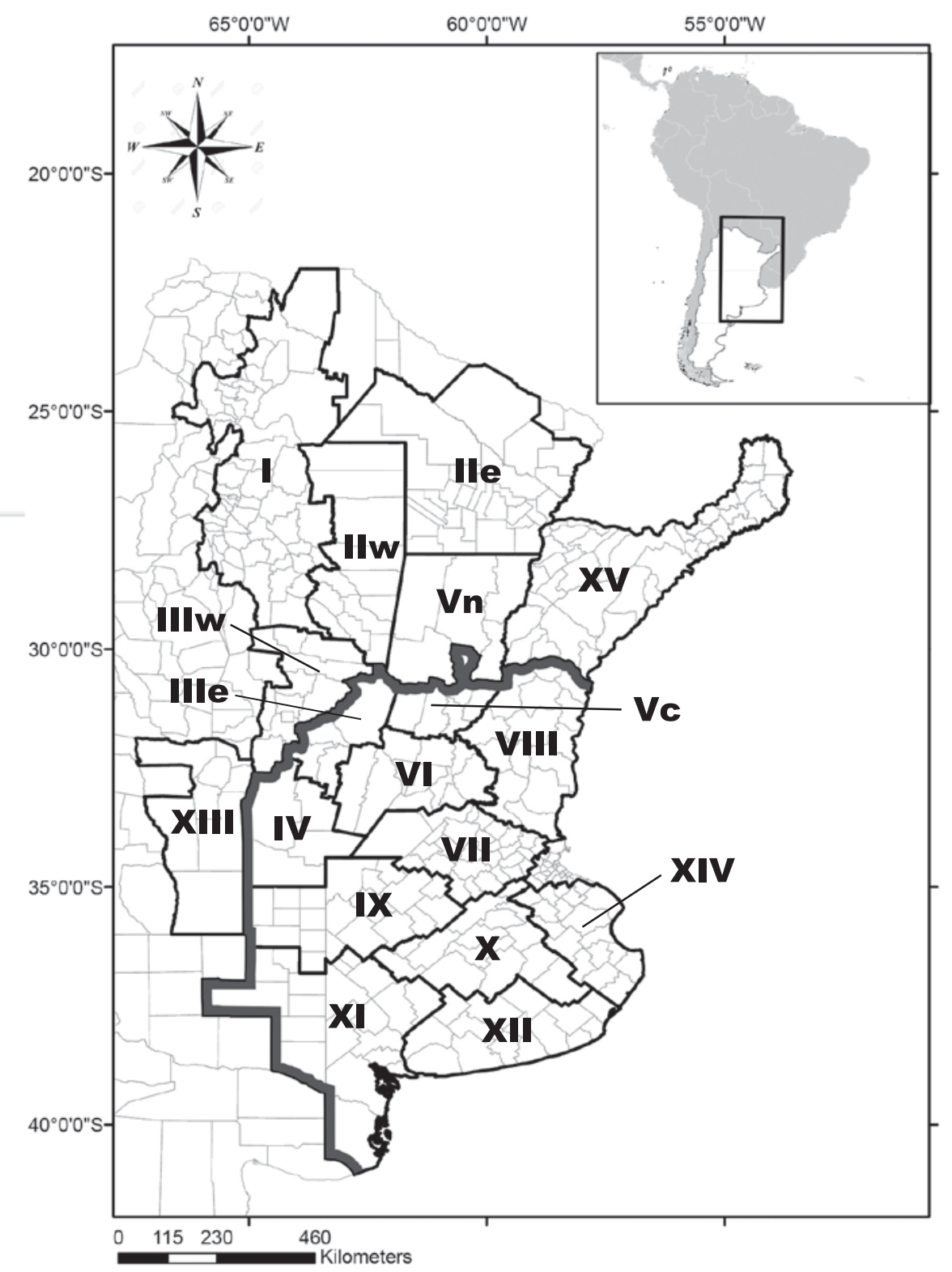

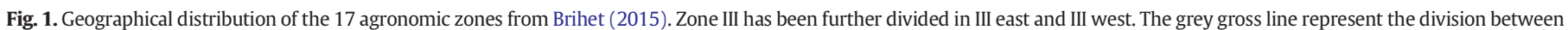
the Pampean (zones III east, IV, V central, VI, VII, VIII, IX, X, XI, XII and XIV) and the extra-Pampean region (zones I, II east, II west, III west, V north, XIII and XV).

For the purpose of this study we added another division which distinguished the territory in two major regions: Pampean and extraPampean (Manuel-Navarrete et al., 2009). Historically, agriculture in Argentina has been developed in the Pampean region where favorable climate and soil conditions were found (represented in Fig. 1 by the zones III east, IV, V central, VI, VII, VIII, IX, X, XII and XIV). However, in the decade of 1990, the adoption of agricultural technology packages consisting of genetically modified seeds, pesticides and no-till farming, helped to expand the agricultural frontier beyond the traditional cultivation regions (Viglizzo et al., 2011). This expansion has been mainly extended into natural forests and grasslands of the Great Chaco, which covers most of the extra-Pampean region (that includes the agronomic zones I, II east, II west, III west, V north, XIII and XV).

Soils, weather and agricultural management vary greatly across the study area. The annual mean temperature ranges from $14{ }^{\circ} \mathrm{C}$ to $22^{\circ} \mathrm{C}$ (zones XII and II, respectively). Annual rainfall varies between 500 and $1440 \mathrm{~mm}$ (zones XIII and XV, respectively). Regarding soils, the Chaco-Pampean plain (all the area considered here) is characterized by soils with greater agricultural aptitude, with prevalence of mollisols and alfisols in both Pampean and extra-Pampean region. However, the extra-Pampean region has climate limitations for agriculture (Zak et al., 2008). More details on agro climatic conditions are shown in Table 1 of Appendix A.

In the agricultural year 2012/2013, the Pampean region produced $88 \%$ of the country's soybeans and maize, while the rest of the country accounting for $12 \%$, with yields for soybeans and maize $46 \%$ and $41 \%$ lower of those found in the Pampas, respectively.

\subsection{Data source}

Data from the agricultural year 2012/2013 was used. The sowing and harvested areas were obtained for each administrative district from the Integrated Agriculture Information System of the Ministry of Agroindustry of Argentina (see Tables 2 and 3 of Appendix A for more details). Yields were obtained from the production reported in each district and the sowing area. Data for each zone was therefore obtained by adding up the corresponding administrative districts. Data on fertilizers, pesticides, type of soil laboring and the usage of seeds were obtained 
from the report Applied Agro Technology Survey from the Buenos Aires Grain Exchange, which are available for each agronomic zone (Brihet, 2015). Since there is no available data for fuel consumption in each agricultural year for Argentina, we have used country-average data from the National Institute of Agricultural Technology (Donato, 2011) of fuel consumption per hectare for each farming operation and for each crop.

\subsection{Inputs}

No-till farming was the dominant practice in Argentina in the 2012/ 2013 agricultural year. National averages showed that $95 \%$ of soybeans and $92 \%$ of maize production was obtained under no-till farming, being genetically modified seeds the most used (Table 1 ). In the case of soybeans the RR variety was the dominant seed, while for maize only $7 \%$ was non-transgenic and $93 \%$ was either Bt or RR/Bt (Brihet, 2015). The national averages for inputs used per hectare are summarized in Table 1 (see Appendix B for more details).

Fuel for operations was obtained from Donato (2011). No-till farming used $15 \mathrm{l}$ and $12.3 \mathrm{l}$ per sown hectare for soybeans and maize, respectively. On the other hand, tillage operations used $40 \mathrm{l} /$ ha for both grains. The use of diesel for harvesting was the same for both types of cultivation, being 10.61 and 15.61 per harvested hectare for soybeans and maize, respectively.

In Table 1, the use of pesticides is shown in kilogram of active ingredients per hectare. These data were obtained from the amounts applied on farms and the concentration of the products given by the manufacturers (see Table 4 of Appendix A). At national level, 30 pesticides were identified, of which 18 were herbicides, 9 insecticides and 3 fungicides. Both soybean and maize cultivation use the same products; however the amount of herbicide applied was higher in maize, while the use of insecticides and fungicides were higher in soybeans. Large zonal variations in the amount and type of pesticides applications were found, probably due to environmental differences, disparity in the criteria among farmers and feeble presence of private and government extension agencies in zones outside the traditional agricultural zones (located in Pampean Region).

The amounts of nitrogen $(\mathrm{N})$, phosphorus $(\mathrm{P})$ and sulfur $(\mathrm{S})$ shown in Table 1 are for synthetic fertilizers. Relevant zonal variations were also found, but in any case the use of fertilizers is historically low throughout Argentina (Viglizzo et al., 2001). Fertilization with manure is not a common practice in large-scale farming in Argentina, particularly in soybeans and maize; more so, there is no data on manure applications for these crops and hence organic fertilizer was not considered here.
The amount of $\mathrm{N}$ in crop residues was estimated by using the method given by the IPCC (2006a). The mass of $\mathrm{N}(\mathrm{kg} \mathrm{N} / \mathrm{ha}$ ) in the above- and below-ground residues was estimated from default values of the IPCC (2006a) by using the present district average for soybean and maize yields from the agricultural year 2012/2013 (IAIS, 2017).

\subsection{GHG emissions and energy use}

The assessment was performed for each agronomic zone described above based on the input data for the agricultural year 2012/2013 mentioned in previous sections (Table 2). The GHG emissions and energy use for the manufacturing of the majority of inputs were obtained from previous studies: maize seeds (West and Marland, 2002); fertilizers (Williams et al., 2010; Camargo et al., 2013); pesticides (West and Marland, 2002); diesel (IPCC, 2006b). Embodied GHG and energy in the provision of these inputs in Argentina are not available. However, the agriculture technological packages used in Argentina are very similar or the same as those in the US or Europe, manufactured locally or imported by the same international suppliers. The difference with the available data for the US and EU could be on the particular electricity mix for the various countries, though the influence on the manufacturing impacts of the inputs can be reasonably assumed to be not significant. Based on information from agronomists, we assume that almost all the soybean farmers in Argentine use their own seeds, so GHG emissions and energy use from soybean seeds production was calculated for each zone using input data from their specific production by iteration.

At present, there are no reports regarding $\mathrm{N}_{2} \mathrm{O}$ emissions factors (EFs) for Argentina. Soil emissions of $\mathrm{N}_{2} \mathrm{O}$ from $\mathrm{N}$ applied by synthetic fertilizers and from residues left on the field were calculated by using the IPCC (2006a) default value of $0.01 \mathrm{~kg} \mathrm{~N}_{2} \mathrm{O}-\mathrm{N}$ per $\mathrm{kg} \mathrm{N}$ applied. Indirect emissions of $\mathrm{N}_{2} \mathrm{O}-\mathrm{N}$ from volatilization of $\mathrm{NH}_{3}$ from the $\mathrm{N}$ applied were estimated by the default emission factor $0.1 \mathrm{~kg} \mathrm{NH}_{3}-\mathrm{N}$ and $\mathrm{NO}_{\mathrm{x}^{-}}$ $\mathrm{N}$ per $\mathrm{kg}$ of $\mathrm{N}$ applied or deposited via residues. Since the proportion of no-till farming is very high in soybean and maize cultivation (see Table 1), and that the practice leaves the crop residues on the field, the assessment of emissions from residues is relevant. We assumed that all residues are left on the ground. Climate could have an influence on the (EFs) for $\mathrm{N}_{2} \mathrm{O}$, which are considered here equal for all regions. This is a limitation of the assessment of GHG emissions in the present study, but unfortunately, we have no data on EFs for Argentina other than the default source from the IPCC (2006a). Due to lack of data, the soil emissions arisen from the application of manures and the indirect emissions $\mathrm{N}_{2} \mathrm{O}-\mathrm{N}$ from lixiviation were not considered (Portela et al., 2006). The present study does not include land use change, although we will discuss this topic in a later section.

Table 1

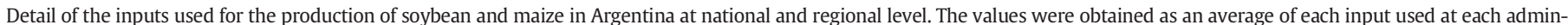
istrative district. For each input, mean values and the corresponding standard error (between brackets) are shown.

\begin{tabular}{|c|c|c|c|c|c|c|c|}
\hline \multirow[b]{2}{*}{ Inputs } & \multirow[b]{2}{*}{ Unit } & \multicolumn{3}{|l|}{ Soybean } & \multicolumn{3}{|l|}{ Maize } \\
\hline & & Country & Pampean & Extra-Pampean & Country & Pampean & Extra-Pampean \\
\hline No-till farming ${ }^{\mathrm{a}}$ & $\%$ & $94.61(0.82)$ & $94.09(1.11)$ & $95.43(1.21)$ & $91.83(1.78)$ & 91.64 (2.49) & $92.14(2.61)$ \\
\hline Diesel $^{\mathrm{b}}$ & 1/ha & $26.76(0.25)$ & $27.02(0.27)$ & $26.36(0.47)$ & $26.69(0.52)$ & $26.87(0.42)$ & $26.42(1.21)$ \\
\hline \multicolumn{8}{|l|}{ Fertilizer $^{a}$} \\
\hline $\mathrm{N}$ & $\mathrm{kg} \mathrm{N} / \mathrm{ha}$ & $5.63(1)$ & $6.03(0.9)$ & $5(2.24)$ & $53.98(4.4)$ & $59.27(5.31)$ & 45.67 (6.95) \\
\hline $\mathrm{P}$ & kg P/ha & $7.42(0.81)$ & $8.46(0.46)$ & $5.79(1.87)$ & $13.14(1.39)$ & $14.85(1.25)$ & $10.45(2.81)$ \\
\hline $\mathrm{S}$ & $\mathrm{kg} \mathrm{S} / \mathrm{ha}$ & $3.72(0.61)$ & $3.81(0.68)$ & $3.59(1.23)$ & $6.13(0.83)$ & 7.05 (1.11) & 4.67 (1.07) \\
\hline Seeds ${ }^{a}$ & $\mathrm{~kg}$ seed/ha & $87.04(7.41)$ & $91.5(9)$ & $80.02(13.21)$ & $22.46(2.84)$ & $24.2(3.61)$ & $19.71(4.75)$ \\
\hline \multicolumn{8}{|l|}{ Pesticides $^{a}$} \\
\hline Herbicides & kg a.i./ha & $4(0.31)$ & $3.91(0.5)$ & $4.13(0.23)$ & $6.94(0.78)$ & $7.25(1.21)$ & $6.45(0.69)$ \\
\hline Insecticides & kg a.i./ha & $0.29(0.03)$ & $0.24(0.02)$ & $0.38(0.07)$ & $0.06(0.02)$ & $0.03(0.01)$ & $0.11(0.04)$ \\
\hline Fungicides & kg a.i./ha & $0.01(0.001)$ & $0.01(0.001)$ & $0.01(0.001)$ & $0.002(0.0007)$ & $0.002(0.0008)$ & $0.002(0.001)$ \\
\hline Crop residues $^{c}$ & kg N/ha & $33.88(1.63)$ & $37.86(1.6)$ & 27.61 (1.39) & $58.28(4.31)$ & $65.28(3.29)$ & $34.43(3.16)$ \\
\hline
\end{tabular}

\footnotetext{
a Brihet (2015).

b Donato (2011).

c Calculated from IPCC (2006a).
} 
Table 2

GHG emissions and energy use of inputs considered for soybean and maize cultivation.

\begin{tabular}{|c|c|c|c|}
\hline Inputs & Unit & $\mathrm{kg} \mathrm{CO}_{2}$-eq/Unit & MJ/Unit \\
\hline Diesel & Liter & $3^{b}$ & $40^{\mathrm{a}}$ \\
\hline \multicolumn{4}{|l|}{ Fertilizer } \\
\hline $\mathrm{N}$ & $\operatorname{kg~N}$ & $9,06^{\mathrm{c}, \mathrm{d}}$ & $54,8^{\mathrm{c}}$ \\
\hline $\mathrm{P}$ & kg P & $0,914^{\mathrm{c}}$ & $10,3^{c}$ \\
\hline S & $\mathrm{kg} \mathrm{S}$ & $0,35^{\mathrm{e}}$ & $5,5^{\mathrm{e}}$ \\
\hline \multicolumn{4}{|l|}{ Seeds } \\
\hline Maize & kg seed & $3,85^{f}$ & $53,4^{\mathrm{f}}$ \\
\hline \multicolumn{4}{|l|}{ Pesticides } \\
\hline Herbicides & $\mathrm{kg}$ active ingredient & $17,2^{\mathrm{f}}$ & $267^{f}$ \\
\hline Insecticides & $\mathrm{kg}$ active ingredient & $18,1^{\mathrm{f}}$ & $285^{\mathrm{f}}$ \\
\hline Fungicides & $\mathrm{kg}$ active ingredient & $19^{f}$ & $289^{f}$ \\
\hline Crop residues & $\mathrm{kg} \mathrm{N}$ & $4,68^{g}$ & \\
\hline \multicolumn{4}{|c|}{ a Includes refinery (Carlsson-Kanyama and Faist, 2000). } \\
\hline \multicolumn{4}{|c|}{ b From IPCC (2006b). } \\
\hline \multicolumn{4}{|c|}{ c From Camargo et al. (2013). } \\
\hline \\
\hline \multicolumn{4}{|c|}{ e From Williams et al. (2010). } \\
\hline \multicolumn{4}{|c|}{ From West and Marland (2002). } \\
\hline \multicolumn{4}{|c|}{ Includes only direct $\mathrm{N}_{2} \mathrm{O}$ emissions from the soil (IPCC, 2006a). } \\
\hline
\end{tabular}

\subsection{GHG and energy efficiency of soybean and maize production}

With data obtained as mentioned for agricultural production and for GHG emissions and energy use, it is interesting to discuss possible indicators which could describe variations in the production of soybean and maize relative to the impacts assessed. For this purpose, here we define GHG efficiency as the amount of soybean or maize obtained per unit of GHG emitted, expressed in units tons of grain per ton of $\mathrm{CO}_{2}$-eq (Clark and Tilman, 2017). Likewise, the energy efficiency is defined here as the amount of soybean or maize obtained per unit of energy used, which will be represented in tons of grain per gigajoule (tons grain/ GJ). These indicators have been previously used to assess the efficiency to obtain protein from a diversity of food items (González et al., 2011). The efficiencies were obtained for both grains throughout the diversity of agronomic zones and regions described above and their correlation with the yield will also be discussed.

\subsection{Data Analysis}

In order to determine differences in crop yields, energy use, GHG emissions and energy and GHG efficiency between Pampean and
Extrapampean agronomic zones we performed ANAVAS. Normal distribution of the model residuals was tested using Shapiro-Wilks analysis and homogeneous variance was analyzed according to Levene's test. Statistical analyses were performed using InfoStat v. 2015 (Di Rienzo et al., 2015). To assess the possible reasons for the differences in crop yields and efficiencies between regions, we have performed different Multivariate Redundancy Analysis (RDA) for each crop using bioclimatic variables and the farm inputs separately (Lepš and Šmilauer, 2003). The

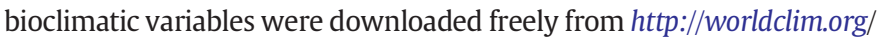
at $140 \mathrm{~km}^{2}$ resolution (Fick and Hijmans, 2017) and mapped in QGIS 2.18 (QGIS Development Team, 2009). The bioclimatic variables used in the analysis where mean annual temperature (MAT), mean diurnal temperature difference (MTDiff), mean annual precipitation (MAP) and the precipitation variation coefficient (PVC). The input variables used where: diesel, seeds, fungicides, herbicides, insecticides, N, P and $\mathrm{S}$ fertilizers. All the analysis were made using CANOCO software (Lepš and Šmilauer, 2003).

\section{Results and discussion}

\subsection{Yields, GHG emissions and energy use per ton of grain}

We find large variations in yields, GHG emissions and energy use per ton of grain across zones and regions, for both soybean and maize. Table 3 depicts the results for each zone. The production of soybean at regional level presents large variations in crop yield, between Pampean and extra-Pampean regions. The mean soybean yield at the Pampean region was $2.62 \pm 0.16$ ton/ha, which is significantly higher than the $1.47 \pm 0.2$ ton/ha yield obtained in the extra-Pampean region $(\mathrm{F}=$ $19.99 ; p=0.0004)$. A similar pattern throughout the regions was observed for the production of maize, for which the mean yield at the Pampean region was $6.02 \pm 0.5$ ton/ha and was significantly higher than the $3 \pm 0.63$ ton/ha yield observed in the extra-Pampean region $(F=14.16$; $p=0.0017)$.

On the other hand, regarding the GHG emissions per ton of crop, we observed that also in the Pampean region the emissions are lower than in the extra-Pampean region. The mean values of GHG at the Pampean region were $0.160 \pm 0.007$ ton $\mathrm{CO}_{2}$-eq/ton of soybean and $0.205 \pm 0.015$ ton $\mathrm{CO}_{2}$-eq/ton of maize. These values were significantly lower than GHG emissions values for soybean and maize at the extra-Pampean region $\left(0.282 \pm 0.057\right.$ ton $\mathrm{CO}_{2}$-eq/ton; $\mathrm{F}=7.14 ; p=0.0167$ and $0.304 \pm 0.038$ ton $\mathrm{CO}_{2}$-eq/ton; $\mathrm{F}=8.14$;

Table 3

Yield, GHG emissions and energy use per ton of soybeans and maize disaggregated in 18 agronomic zones of Argentina.

\begin{tabular}{|c|c|c|c|c|c|c|c|}
\hline \multirow[t]{3}{*}{ Region } & \multirow[t]{3}{*}{ Agronomic zone } & \multicolumn{3}{|c|}{ Soybean } & \multicolumn{3}{|l|}{ Maize } \\
\hline & & Yield & GHG & Energy & Yield & GHG & Energy \\
\hline & & ton/ha & ton $\mathrm{CO}_{2}$-eq/ton & $\mathrm{GJ} /$ ton & ton/ha & ton $\mathrm{CO}_{2}$-eq/ton & $\mathrm{GJ} /$ ton \\
\hline \multirow[t]{11}{*}{ Pampean } & III east & 2.285 & 0.167 & 1.142 & 5.818 & 0.193 & 1.429 \\
\hline & IV & 2.239 & 0.191 & 1.300 & 5.241 & 0.180 & 1.142 \\
\hline & V central & 3.064 & 0.150 & 0.949 & 4.968 & 0.234 & 1.664 \\
\hline & VI & 3.487 & 0.134 & 0.805 & 8.754 & 0.157 & 0.984 \\
\hline & VII & 3.562 & 0.117 & 0.731 & 8.909 & 0.154 & 0.941 \\
\hline & VIII & 2.471 & 0.201 & 1.664 & 6.564 & 0.208 & 1.680 \\
\hline & IX & 2.606 & 0.160 & 1.043 & 5.500 & 0.198 & 1.274 \\
\hline & $\mathrm{X}$ & 2.399 & 0.153 & 1.026 & 7.109 & 0.160 & 1.009 \\
\hline & XI & 2.144 & 0.153 & 0.951 & 1.911 & 0.306 & 1.984 \\
\hline & XII & 1.833 & 0.176 & 1.238 & 4.993 & 0.271 & 1.701 \\
\hline & XIV & 2.699 & 0.153 & 1.020 & 6.451 & 0.191 & 1.268 \\
\hline \multirow[t]{7}{*}{ Extra-Pampean } & I & 0.783 & 0.590 & 4.542 & 2.041 & 0.360 & 2.821 \\
\hline & II east & 1.010 & 0.363 & 2.866 & 1.967 & 0.315 & 2.520 \\
\hline & II west & 1.644 & 0.185 & 1.471 & 2.836 & 0.249 & 1.817 \\
\hline & III west & 1.635 & 0.221 & 1.643 & 4.565 & 0.234 & 1.819 \\
\hline & V north & 2.251 & 0.176 & 1.225 & 3.355 & 0.195 & 1.381 \\
\hline & XIII & 1.701 & 0.177 & 1.344 & 4.125 & 0.281 & 2.064 \\
\hline & $\mathrm{XV}$ & 1.295 & 0.260 & 2.355 & 2.101 & 0.493 & 3.874 \\
\hline
\end{tabular}


$p=0.0115$; respectively). The mean energy use per ton of crop in the Pampean region was $1.079 \pm 0.077 \mathrm{GJ} /$ ton for soybean and $1.371 \pm$ $0.105 \mathrm{GJ} /$ ton for maize. These values were significantly lower than mean energy use values for soybean and maize at the extraPampean region $(2.207 \pm 0.449 \mathrm{GJ} /$ ton; $\mathrm{F}=9.53 ; p=0.0071$ and $2.328 \pm 0.315 \mathrm{GJ} /$ ton; $\mathrm{F}=11.7 ; p=0.0035$; respectively).

When data is weighted and analyzed at national level, the production of soybeans in Argentina has a mean yield of 2.458 ton/ha. To reach this production the mean amount of GHG emitted to the atmosphere was 0.165 ton $\mathrm{CO}_{2}$-eq/ton and the energy used was $1.127 \mathrm{GJ} /$ ton of soybean. On the other hand, the production of maize in Argentina has a mean yield of 5.297 ton/ha, with GHG emissions of 0.199 ton $\mathrm{CO}_{2}$-eq/ton and an energy used associated of $1.352 \mathrm{GJ} / \mathrm{ton}$.

\subsection{Comparison with other studies}

There are previous studies which assessed the GHG emissions and energy use of soybean and maize production or their subproducts worldwide. Raucci et al. (2015) investigated 55 farms in Brazil (Mato Grosso State) during three agricultural years, obtaining an average of GHG emissions between 0.102 and 0.347 ton $\mathrm{CO}_{2}$-eq/ton of soybean produced (yields of 2.33 to 3.8 ton/ha). Also in Brazil, by using input data from national averages, González et al. (2011) obtained GHG emissions of 0.120 ton $\mathrm{CO}_{2}$-eq/ton and energy use of $1.55 \mathrm{GJ} /$ ton of soybean (yield of 2.2 ton/ha). For China, Knudsen et al. (2010) studied conventional and organic farming of soybean, obtaining 0.156 and 0.263 ton $\mathrm{CO}_{2}$-eq/ton and energy use at farm-gate of 0.770 and $1.700 \mathrm{GJ} /$ ton, respectively (for yields of 2.78 and 3.08 ton/ha). Considering the various locations and uncertainties, all of these previous studies are found in good agreement with the present results. On different production characteristics than Argentina, an interesting case was studied by Mohammadi et al. (2013), comprising 94 farms of Golestan province in Iran where irrigation and high fertilizer inputs were used, leading to 0.957 ton $\mathrm{CO}_{2}$-eq/ton and 4 to $20 \mathrm{GJ} /$ ton at farm-gate (for an average yield of $3.23 \mathrm{ton} / \mathrm{ha}$ ). There are three previous works which dealt with soybean-based products in Argentina, like soymeal and biodiesel (Dalgaard et al., 2008; Panichelli et al., 2009; Castanheira and Freire, 2013), but the data for agricultural inputs and operations used were based on national averages and the results were not reported at farm-gate.

In the case of maize cultivation, Grassini and Cassman (2012) found GHG emissions of 0.295 ton $\mathrm{CO}_{2}$-eq/ton and an energy use of $2.27 \mathrm{GJ} / \mathrm{ton}$ at farm gate in Nebraska, USA, for high-yield maize farms (13.2 ton/ha). A work by Kim et al. (2014) performed a meta-study of maize production in the USA and found GHG emissions between - 0.027 (carbon sequestration) and 0.436 ton $\mathrm{CO}_{2}$-eq/ton and energy use from 1.44 to 3.5 $\mathrm{GJ} /$ ton at farm-gate ( 7.65 to 13.2 ton/ha). In Canada, Jayasundara et al. (2014) obtained values of 0.281 ton $\mathrm{CO}_{2}$-eq/ton and $1.808 \mathrm{MJ} /$ ton for a yield of 9.4 ton/ha. These values are higher than those obtained in the present study for the whole country and for Pampean region averages; however, they are in agreement with values observed at extraPampean region.

In general, GHG emissions and energy use per ton of soybeans and maize cultivated in Argentina resulted lower in comparison with those cultivated in other countries, which reported similar or higher yields than the national average of the present work. The differences in GHG emissions and energy use can be attributed to the smaller amount of fertilizers used in Argentina and to the dominance of no-till farming practices (see Table 1), which requires less fuel than conventional farming (Mileusnić et al., 2010).

\subsection{GHG emissions and energy efficiencies}

The amount of soybean grain obtained for a unit of GHG emitted was significantly higher for the Pampean region $(\mathrm{F}=13.38$; $p=0.0021)$. At this region, the GHG efficiency obtained was $6.404 \pm 0.301$ ton/ton $\mathrm{CO}_{2}$ eq, while at the extra-Pampean region was $4.223 \pm 0.585$ ton soybean/ ton $\mathrm{CO}_{2}$-eq. The same pattern was observed for the amount of soybean obtained per $1 \mathrm{GJ}$ of energy used: at the Pampean region the energy efficiency was significantly higher $(0.971 \pm 0.065$ ton $/ \mathrm{GJ})$ than at the extra-Pampean ( $0.549 \pm 0.84$ ton/GJ; $F=16.24 ; p=0.0010)$. For maize the comparison is similar, at the Pampean region the grain obtained per unit of GHG emitted were $5.107 \pm 0.319$ ton maize/ton $\mathrm{CO}_{2}$-eq, while at the extra-Pampean region the energy efficiency were $3.564 \pm 0.386$ ton soybean/ton $\mathrm{CO}_{2}$-eq. ( $\left.\mathrm{F}=9.34 ; p=0.0075\right)$. Regarding the amount of maize obtained per GJ of energy used, at the Pampean region was significantly higher $(0.773 \pm 0.058$ ton $)$ than at the extraPampean region $(0.474 \pm 0.058$ ton; $F=11.91 ; p=0.0033)$. The differences in GHG emissions and energy use efficiencies between the Pampean and the extra-Pampean regions, for both crops, are consistent with the fact that agricultural performances are different within regions and will be discussed below.

At a national level, the GHG efficiency of soybean production for Argentina was 6.061 ton/ton $\mathrm{CO}_{2}$-eq emitted to the atmosphere, while 0.887 ton of soybeans were produced per GJ of energy used. Similar values were obtained for maize production, the GHG efficiency was 5.013 ton/ton $\mathrm{CO}_{2}$-eq emitted to the atmosphere and 0.740 ton of maize were produced per each GJ of energy used. Table 6 in Appendix A summarizes the GHG and energy efficiencies for all zones and regions studied.

Fig. 2 depict the GHG and energy efficiencies for soybean and maize cultivation at the different zones and regions in Argentina. Both crops led to linear interpolations with $r$ values of 0.91 and 0.92 for soybean, and 0.87 and 0.88 for maize, being the $p$-value in all cases $<0.001$, which demonstrated a strong correlation between efficiencies and yields. Even though the large differences in efficiencies found for the Pampean and extra-Pampean regions, the efficiencies for all zones correlate in the linear regression. The Pampean region is significantly more efficient in the emissions of GHG and use of energy per ton of grain produced, and at the same time, it is in this region of Argentina where higher yields of soybean and maize production are obtained. In addition, efficiencies of the extra-Pampean zones are lower than the country averages, while in most Pampean zones efficiencies are mostly above the national average.

The largest GHG and energy efficiencies were found in zones VI and VII for soybeans, and in zones IV, VI, VII and X for maize, being VI and VII the most efficient for both grains. These two zones are located in the most suitable croplands of the country, called "nucleus zones". Despite larger amount of inputs used in zones VI and VII (Tables 1 and 2, Appendix B), larger yields lead to higher efficiencies as shown Fig. 2. On the other hand, the lowest efficiencies were found in the zones of the extra-Pampean region, with zonal variation in efficiencies reaching up to 4-fold lower than in the those in nucleus zone. With the exception of zone XI, all zones into the Pampean region are equal or above the average yield for the country, while the zones on the extra-Pampean region lead to equal or lower yields than the country average. In the next section, we will show results and discuss the multivariate approach to explain the differences found here.

\subsection{Differences across zones and regions}

Here we show the results of the multivariate Redundancy Analysis (RDA), in which we explore the main reasons of the differences in yields and GHG and energy efficiencies across the agronomic zones and regions (Figs. 3 and 4).

The RDA analysis of climatic variables for soybean and maize, and for both crops we found similar trends. For soybean the adjusted explain variation was $42.25 \%(\mathrm{~F}=3.9 ; p=0.01)$. Axis 1 explains $39.86 \%$ of the adjusted explain variation and Axis $2.39 \%$. On the other hand, in the analysis of maize crops the adjusted explain variation was $57.54 \%(\mathrm{~F}=6.4 ; p=0.002)$. In this case Axis 1 explains $56.27 \%$ of the adjusted explain variation and Axis $21.27 \%$. 

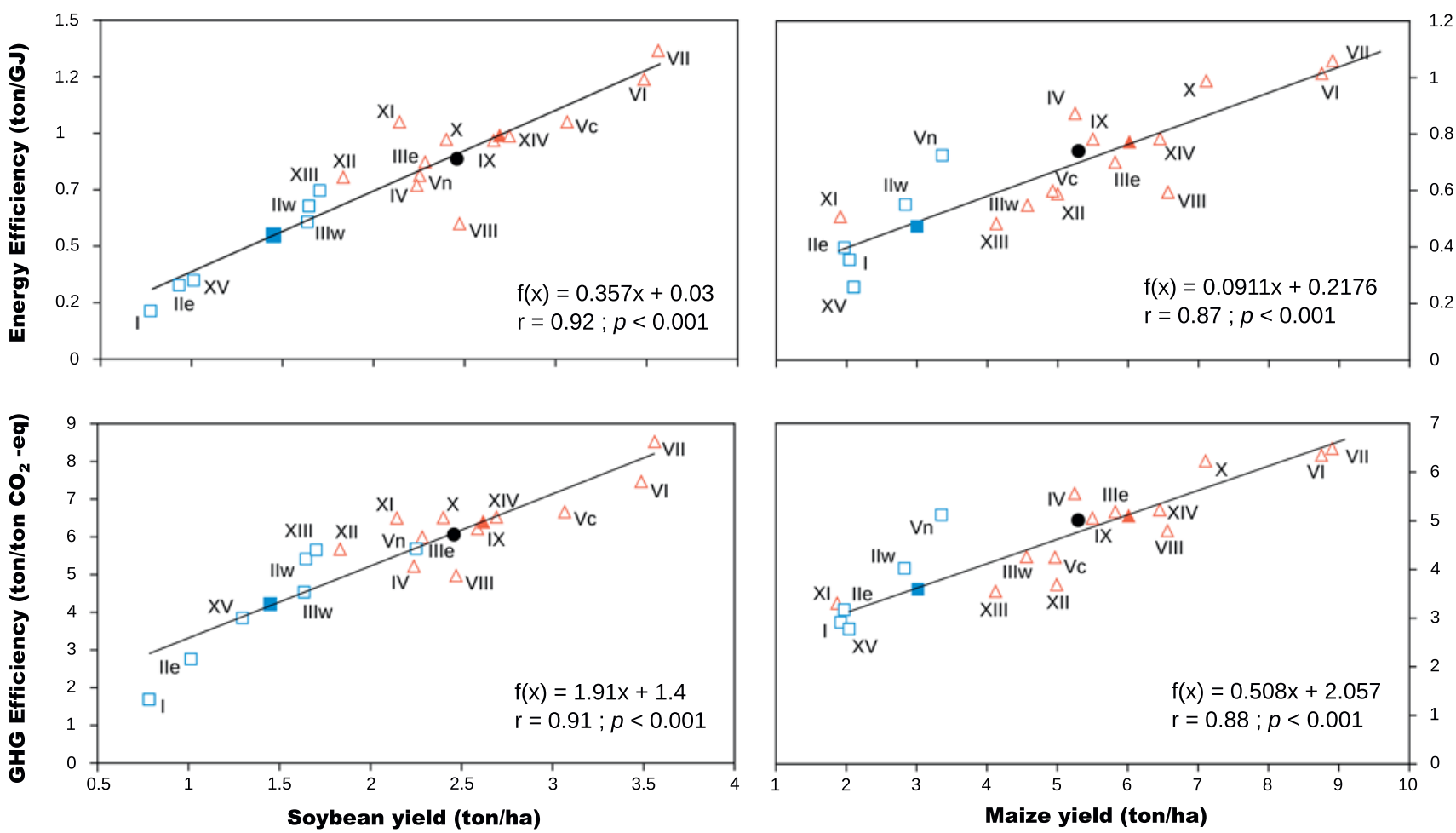

Country mean

$\Delta$ Pampean region mean

Extra-pampean region mean

$\triangle$ Pampean zones $\square$ Extra-pampean zones

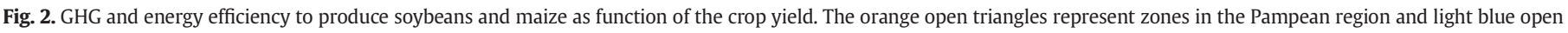

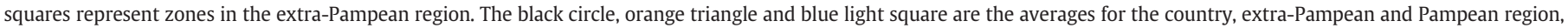
respectively. (For interpretation of the references to colour in this figure legend, the reader is referred to the web version of this article.)

For both crops negative values of Axis 1 indicates that the zones where they are produced have higher yields, GHG emissions and energy efficiencies associated with higher mean annual precipitations and they are from the Pampean region (orange triangles). Whereas positive values of Axis 1 indicates that the zones where the crops are produced have lower yields, GHG emissions and energy

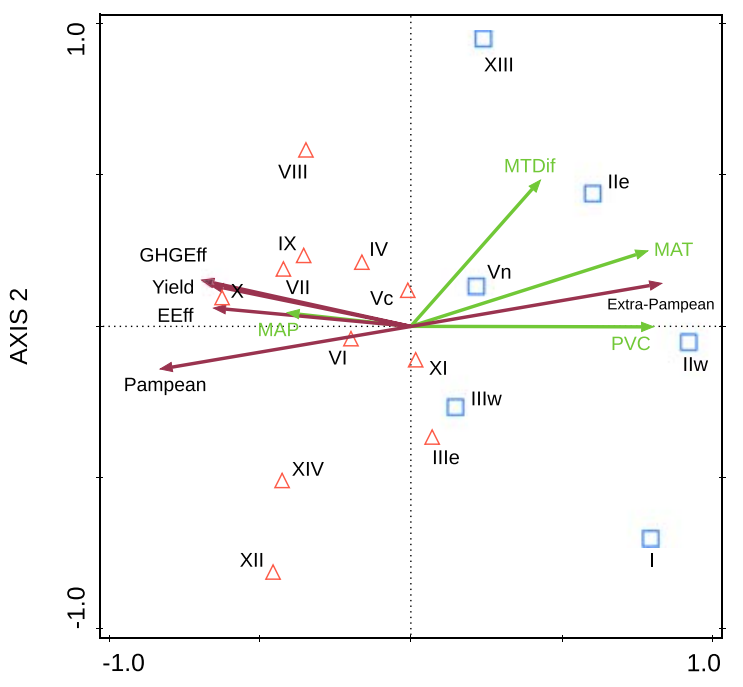

AXIS 1 efficiencies associated with higher mean annual temperature, mean diurnal temperature differences and precipitation variation coefficients and they are from the extra-Pampean region (blue light squares).

Fig. 4 shows the RDA analysis of the inputs involved in the production of soybean and maize crops. In these case the input variables used in both

Soybean

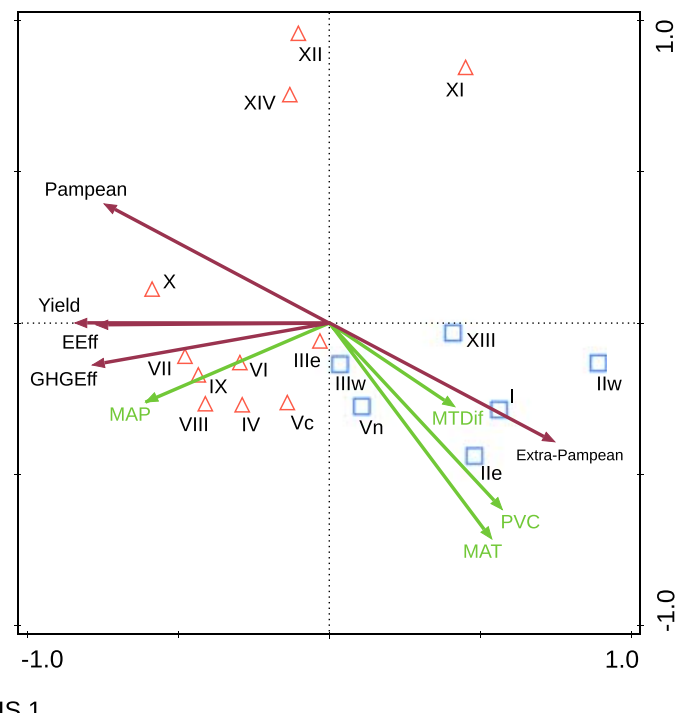

Maize

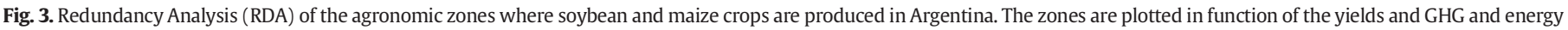

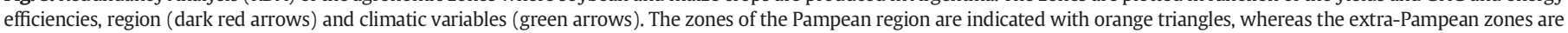
indicated with blue light squares. (For interpretation of the references to colour in this figure legend, the reader is referred to the web version of this article.) 

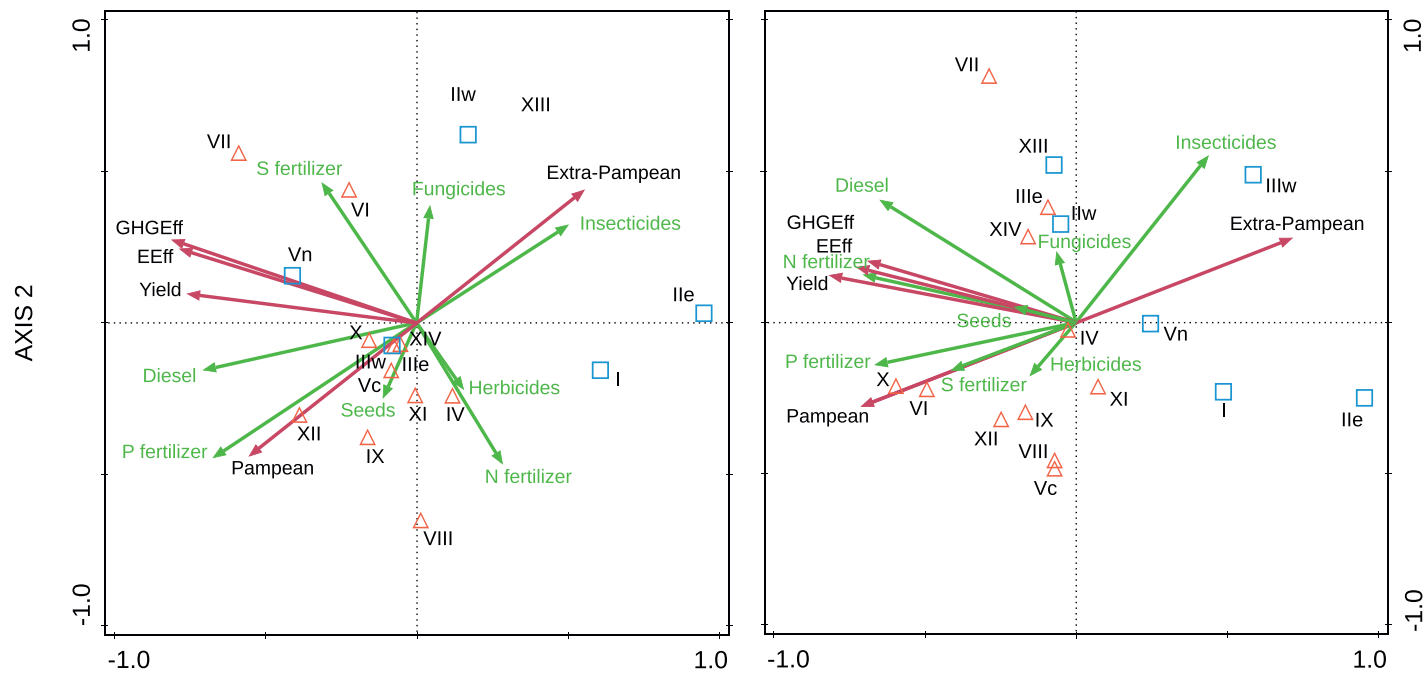

Soybean

AXIS 1

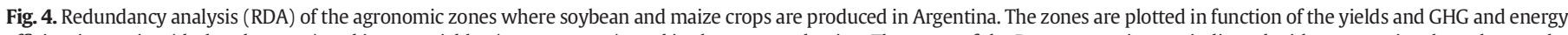

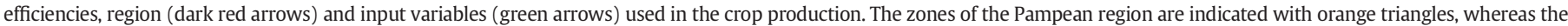

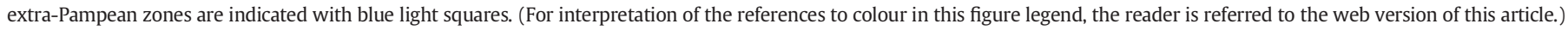

crops did not explain significantly the differences in yield, GHG emissions and energy efficiencies between the zones and agronomic regions. For soybean crops the adjusted explain variation was $21.12 \%(\mathrm{~F}=1.5 ; p=$ $0.214)$ and for maize was $21.24 \%(\mathrm{~F}=1.5 ; p=0.216)$.

According to the RDA, the most important variable for GHG emissions and energy efficiencies is climate, particularly mean annual precipitation, which is consistent with the fact that rainfall and crop water availability are among the most important limiting factors in rainfed cropping systems around the world (Hall et al., 1992). Although some agronomic zones presents rainfall patterns that could be considered suitable for cropping, water condition for crops is not only determined by rainfall. Initial water available in soil, effective infiltration, soil water retention capacity, vapor pressure deficit, and specific moment of water stress relative to critical period of yield determination in each crop also influences the crop response (Andrade and Satorre, 2015).

\subsection{Final considerations and further research}

Even though it was not included in the present study, let us discuss two aspects of land use change that might affect results for emissions and efficiencies and could even widen differences found between Pampean and extra-Pampean regions: (i) carbon emissions associated to land use change; and (ii) allocation of indirect land use change carbon emissions. These factors would affect in the same way the results for both crops studied here, so we will discuss the possible effects using soybean as an example.

(i) Carbon emissions associated to land use change. Land use change is one of the major contributors to climate change (Tubiello et al., 2015). Unlike the Pampean region where agriculture has been practiced since the beginning of the 20th century, the extraPampean region underwent an intense conversion into agriculture since the 1990s (Viglizzo et al., 2011). The sharp increase in the prices of commodities like soybeans and the increase in global meat consumption in the last twenty years have led to a rapid expansion of the agricultural frontier in the region (Gasparri et al., 2013). Additionally, changes in local currency exchange rates, the availability of technological packages (no-till farming and genetically modified crops), and regional increases in precipitation prompted abrupt changes in the rates of deforestation (Zak et al., 2008). Since then, the extra-Pampean region has presented the highest rates of land use change in Argentina over the last 20 years (Gasparri and Grau, 2009; Vallejos et al., 2015; Volante et al., 2016). This process occurred mainly in the Great Chaco, which is the most extensive dry forest ecosystem in South America and covers almost the entire extra-Pampean region (Fehlenberg et al., 2017). In a recent work, Baumann et al. (2017) found that land use change between 1985 and 2013 in the Great Chaco emitted a total of $1708 \mathrm{Tg}$ of $\mathrm{CO}_{2}$. Of this total, the land use change from forests to croplands is responsible for the $25 \%$ of total emissions $\left(427 \mathrm{Tg}\right.$ of $\mathrm{CO}_{2}$ ), while the change from grasslands to crops is responsible for $7 \%$ of total emissions $\left(120 \mathrm{Tg}\right.$ of $\left.\mathrm{CO}_{2}\right)$. So, if we would include the emissions of land use change in the carbon footprints the differences between the extraPampean and the Pampean region would be even higher than the results found in the present study (Flynn et al., 2012).

(ii) Allocation of indirect land use change carbon emissions. One of the most complicated items of the carbon footprint analysis is the carbon emissions allocation when land use change has more than one deforestation driver (Persson et al., 2014). In this sense, in Argentina occurs a similar process that happens in Brazil (Gasparri and Waroux, 2015). While cattle ranching are the principal direct (or proximate) driver of forest loss in the Great Chaco, the deforestation frontier in the region is likely primarily fueled by the global demand for soybeans (Fehlenberg et al., 2017). This process is explained by the displacement of livestock occurred in the last 20 years, where grasslands and pastures of the Pampean region were converted into annual croplands, and cattle was moved to less suitable lands for crop production on the extraPampean region causing deforestation (Viglizzo et al., 2011). As Persson et al. (2014) suggested, the soybean produced in the Pampean region should share part of the carbon emissions occurred in the Great Chaco with beef production. This will reduce the differences in GHG emissions and energy efficiencies of soybean between Pampean and extra-Pampean regions. However, there is no established consensus methodology for calculating GHG emissions allocations from land use change in carbon footprints and consequently most carbon footprints of agricultural commodities have so far not included these effects. 


\section{Conclusions}

This work deals with the assessment of the carbon and energy footprint of soybean and maize (as well as the carbon and energy efficiencies), the two most important crops produced in Argentina. We have performed a detailed analysis of 18 agronomic zones comprising 1.53 million $\mathrm{km}^{2}$. The efficiencies for national averages obtained for soybeans were 6.061 ton/ton $\mathrm{CO}_{2}$-eq emitted to the atmosphere, while 0.887 ton of soybean were produced per GJ of energy used; and for maize 5.013 ton/ton $\mathrm{CO}_{2}$-eq emitted to the atmosphere and 0.740 ton of maize were produced per each GJ of energy used. Yield and GHG emissions and energy efficiencies found for both crops were significantly higher at the Pampean region than in extra-Pampean region, an area where large scale farming has been practiced relatively recently.

To assess the main reasons for these differences we performed different multivariate Redundancy Analysis (RDA) for each crop using bioclimatic variables and the farm inputs separately. We have found that the large differences of yields, GHG and energy efficiencies between agronomic zones and regions for soybean and maize are mainly driven by climate, particularly mean annual precipitation.

This study contributes to understand the carbon and energy footprint of soybean and maize production throughout a vast agricultural territory in Argentina, and demonstrated significant differences in impacts and resource use across traditional (Pampean) and newer (extra-Pampean) productive regions. The zones with lower efficiencies are those were large scale farming were not practiced until recent times due to their limiting agro climatic conditions. Hence, significant lower yields and GHG and energy efficiencies question the environmental viability of expanding the agricultural frontier to less suitable lands for crop production.

\section{Acknowledgment}

The authors want to thank tree anonymous reviewers for their valuable comments and suggestions, which helped to improve the manuscript. Also, the support of the National Research Council of Argentina (CONICET) for the PhD fellowship of E.M.A. and D.C., the Post-doctoral fellowship of A.C. and the senior position of A.D.G. are acknowledged. We also want to thanks to Sofia Gayo from the Buenos Aires Grain Exchange for the provision of data.

\section{Appendix. Supplementary data}

Supplementary data to this article can be found online at https://doi. org/10.1016/j.scitotenv.2017.12.286.

\section{References}

Andrade, J.F., Satorre, E.H., 2015. Single and double crop systems in the Argentine pampas: environmental determinants of annual grain yield. Field Crop Res. 177, 137-147.

Baumann, M., Gasparri, I., Piquer-Rodríguez, M., Gavier Pizarro, G., Griffiths, P., Hostert, P., Kuemmerle, T., 2017. Carbon emissions from agricultural expansion and intensification in the Chaco. Glob. Chang. Biol. 23, 1902-1916.

Bolsa de Cereales de Buenos Aires (BCBA - Buenos Aires Grain Exchange), 2017. (in Spanish). Available at:. http://www.bolsadecereales.com/, Accessed date: 9 September 2017.

Brihet, J.M., 2015. Relevamiento de Tecnología Agrícola Aplicada (Applied Agro Technology Survey): 2012/2013. Bolsa de Cereales de Buenos Aires. Buenos Aires, Argentina (in Spanish). Available at:. http://www.bolsadecereales.com, Accessed date: 9 September 2017.

Camargo, G.G., Ryan, M.R., Richard, T.L., 2013. Energy use and greenhouse gas emissions from crop production using the farm energy analysis tool. Bioscience 63, 263-273.

Carlsson-Kanyama, A., Faist, M., 2000. Energy Use in the Food Sector: A Data Survey. Swedish Environmental Protection Agency, Stockholm, Sweden Available at:. http:// citeseerx.ist.psu.edu/viewdoc/download?rep =rep1\&type $=$ pdf\&doi $=$ 10.1.1.205.8375, Accessed date: 9 September 2017.

Castanheira, É.G., Freire, F. 2013. Greenhouse gas assessment of soybean production: implications of land use change and different cultivation systems. J. Clean. Prod. 54, 49-60.
Clark, M., Tilman, D., 2017. Comparative analysis of environmental impacts of agricultural production systems, agricultural input efficiency, and food choice. Environ. Res. Lett. 12,064016

Dalgaard, R., Schmidt, J., Halberg, N., Christensen, P., Thrane, M., Pengue, W.A., 2008. LCA of soybean meal. Int. J. Life Cycle Assess. 13, 240.

De Sy, V., Herold, M., Achard, F., Beuchle, R., Clevers, J.G.P.W., Lindquist, E., Verchot, L., 2015. Land use patterns and related carbon losses following deforestation in South America. Environ. Res. Lett. 10, 124004.

Di Rienzo, J.A., Casanoves, F., Balzarini, M.G., Gonzalez, L., Tablada, M., Robledo, Y.C., 2015. Grupo InfoStat, FCA. 464 Universidad Nacional de Córdoba, Argentina Available at:. www.infostat.com.ar, Accessed date: 9 September 2017.

Donato, L.B., 2011. Estimación del consumo potencial de gasoil para las tareas agrícolas, transporte y secado de granos en el sector agropecuario. Available at:. http:// inta.gob.ar/sites/default/files/script-tmp-consumo3.pdf , Accessed date: 9 September 2017.

Edgerton, M.D., 2009. Increasing crop productivity to meet global needs for feed, food, and fuel. Plant Physiol. 149, 7-13.

FAO, 2017. Food Outlook: Biannual Report on Global Food Market. Food and Agriculture Organization, Rome Available at:. http://www.fao.org/3/a-i6198e.pdf, Accessed date: 9 September 2017.

FAOSTATS, 2017. http://www.fao.org/faostat>, Accessed date: 9 September 2017.

Fehlenberg, V., Baumann, M., Gasparri, N.I., Piquer-Rodriguez, M., Gavier-Pizarro, G., Kuemmerle, T., 2017. The role of soybean production as an underlying driver of deforestation in the South American Chaco. Glob. Environ. Chang. 45, 24-34.

Fick, S.E., Hijmans, R.J., 2017. WorldClim 2: new 1-km spatial resolution climate surfaces for global land areas. Int. J. Climatol. 37, 4302-4315.

Flynn, H.C., Keller, E., King, H., Sim, S., Hastings, A., Wang, S., Smith, P., 2012. Quantifying global greenhouse gas emissions from land-use change for crop production. Glob. Chang. Biol. 18, 1622-1635.

Foley, J.A., Ramankutty, N., Brauman, K.A., Cassidy, E.S., Gerber, J.S., Johnston, M., ... Balzer, C., 2011. Solutions for a cultivated planet. Nature 478, 337-342.

Gasparri, N.I., Grau, H.R., 2009. Deforestation and fragmentation of Chaco dry forest in NW Argentina (1972-2007). For. Ecol. Manag. 258, 913-921.

Gasparri, N.I., Waroux, Y.L.P., 2015. The coupling of South American soybean and cattle production frontiers: new challenges for conservation policy and land change science. Conserv. Lett. 8, 290-298.

Gasparri, N.I., Grau, H.R., Angonese, J.G., 2013. Linkages between soybean and neotropical deforestation: coupling and transient decoupling dynamics in a multi-decadal analysis. Glob. Environ. Chang. 23, 1605-1614.

Godfray, H.C.J., Garnett, T., 2014. Food security and sustainable intensification. Philos. Trans. R. Soc. B 369, 20120273.

González, A.D., Frostell, B., Carlsson-Kanyama, A., 2011. Protein efficiency per unit energy and per unit greenhouse gas emissions: potential contribution of diet choices to climate change mitigation. Food Policy 36, 562-570.

Grassini, P., Cassman, K.G., 2012. High-yield maize with large net energy yield and small global warming intensity. Proc. Natl. Acad. Sci. U. S. A. 109, 1074-1079.

Hall, A.J., Rebella, C.M., Ghersa, C.M., Culot, J.Ph., 1992. Field-crop systems of the Pampas. In: Pearson, C.J. (Ed.), Field Crop Ecosystems Series: Ecosystems of the World. Elsevier Science Publishers B.V., Amsterdam, pp. 413-450.

Integrated Agriculture Information System (IAIS) - Sistema Integrado de Información Agropecuaria, 2017. Ministerio de Agroindustria de Argentina (in Spanish). Ministry of Agroindustry of Argentina. Available at:. https://datos.magyp.gob.ar/, Accessed date: 9 September 2017

IPCC, 2006a. Intergovernmental panel on climate change. N2O emissions from managed soils, and $\mathrm{CO} 2$ emissions from lime and urea application. IPCC guidelines for National Greenhouse gas Inventories, prepared by the National Greenhouse gas Inventories Programme - vol. 4, Agriculture, forestry and other land use. National Greenhouse Gas Inventories Program. IGES, Japan.

IPCC, 2006b. Intergovernmental panel on climate change. Mobile combustion. IPCC guidelines for National Greenhouse gas Inventories, prepared by the National Greenhouse gas Inventories Programme - vol. 2, energy. National Greenhouse Gas Inventories Program. IGES, Japan.

IPCC, 2007. Intergovernmental Panel on Climate Change. IPCC Fourth Assessment Report (AR4): Synthesis Report. Geneva, Switzerland, Intergovernmental Panel on Climate Change.

Jayasundara, S., Wagner-Riddle, C., Dias, G., Kariyapperuma, K.A., 2014. Energy and greenhouse gas intensity of corn (Zea mays L.) production in Ontario: a regional assessment. Can. J. Soil Sci. 94, 77-95.

Kastner, T., Rivas, M.J.I., Koch, W., Nonhebel, S., 2012. Global changes in diets and the consequences for land requirements for food. Proc. Natl. Acad. Sci. U. S. A. 109, 6868-6872.

Kim, S., Dale, B.E., Keck, P., 2014. Energy requirements and greenhouse gas emissions of maize production in the USA. BioEnergy Res. 7, 753-764.

Knudsen, M.T., Yu-Hui, Q., Yan, L., Halberg, N., 2010. Environmental assessment of organic soybean (Glycine max.) imported from China to Denmark: a case study. J. Clean. Prod. $18,1431-1439$.

Lepš, J., Šmilauer, P., 2003. Multivariate Analysis of Ecological Data Using CANOCO. Cambridge University Press.

Manuel-Navarrete, D., Gallopín, G.C., Blanco, M., Díaz-Zorita, M., Ferraro, D.O., Herzer, H., ... Satorre, E.H., 2009. Multi-causal and integrated assessment of sustainability: the case of agriculturization in the Argentine pampas. Environ. Dev. Sustain. 11, 621-638.

Mikkola, H.J., Ahokas, J., 2010. Indirect energy input of agricultural machinery in bioenergy production. Renew. Energy 35, 23-28.

Mileusnić, Z.I., Petrović, D.V., Đević, M.S., 2010. Comparison of tillage systems according to fuel consumption. Energy 35, 221-228. 
Mohammadi, A., Rafiee, S., Jafari, A., Dalgaard, T., Knudsen, M.T., Keyhani, A., .. Hermansen, J.E., 2013. Potential greenhouse gas emission reductions in soybean farming: a combined use of life cycle assessment and data envelopment analysis. J. Clean. Prod. 54, 89-100.

Panichelli, L., Dauriat, A., Gnansounou, E., 2009. Life cycle assessment of soybean-based biodiesel in Argentina for export. Int. J. Life Cycle Assess. 14, 144-159.

Pelletier, N., Audsley, E., Brodt, S., Garnett, T., Henriksson, P., Kendall, A., ... Troell, M., 2011. Energy intensity of agriculture and food systems. Annu. Rev. Environ. Resour. 36, 223-246.

Persson, U.M., Henders, S., Cederberg, C., 2014. A method for calculating a land-use change carbon footprint (LUC-CFP) for agricultural commodities-applications to Brazilian beef and soy, Indonesian palm oil. Glob. Chang. Biol. 20, 3482-3491.

Portela, S.I., Andriulo, A.E., Sasal, M.C., Mary, B., Jobbágy, E.G., 2006. Fertilizer vs. organic matter contributions to nitrogen leaching in cropping systems of the pampas: ${ }^{15} \mathrm{~N}$ application in field lysimeters. Plant Soil 289, 265-277.

QGIS Development Team, 2009. QGIS Geographic Information System. Open Source Geospatial Foundation Available online on. http://qgis.osgeo.org.

Raucci, G.S., Moreira, C.S., Alves, P.A., Mello, F.F., de Almeida Frazão, L., Cerri, C.E.P., Cerri, C.C., 2015. Greenhouse gas assessment of Brazilian soybean production: a case study of Mato Grosso State. J. Clean. Prod. 96, 418-425.

Trigo, E., Cap, E., Malach, V., Villarreal, F., 2009. The case of zero-tillage technology in Argentina. IFPRI Discussion Paper 00915. Institute, International Food Policy Research.

Tubiello, F.N., Salvatore, M., Ferrara, A.F., House, J., Federici, S., Rossi, S., ... Prosperi, P., 2015. The contribution of agriculture, forestry and other land use activities to global warming, 1990-2012. Glob. Chang. Biol. 21, 2655-2660.

USDA - United States Department of Agriculture, 2017. World agricultural production. Foreign Agricultural Service/USDA. Circular series WAP 02-17. Available at:. https:// apps.fas.usda.gov/psdonline/circulars/production.pdf, Accessed date: 9 September 2017.

Vallejos, M., Volante, J.N., Mosciaro, M.J., Vale, L.M., Bustamante, M.L., Paruelo, J.M., 2015. Transformation dynamics of the natural cover in the Dry Chaco ecoregion: a plot level geo-database from 1976 to 2012. J. Arid Environ. 123, 3-11.

Viglizzo, E.F., Lértora, F., Pordomingo, A.J., Bernardos, J.N., Roberto, Z.E., Del Valle, H., 2001 Ecological lessons and applications from one century of low external-input farming in the pampas of Argentina. Agric. Ecosyst. Environ. 83, 65-81.

Viglizzo, E.F., Frank, F.C., Carreno, L.V., Jobbagy, E.G., Pereyra, H., Clatt, J., ... Ricard, M.F. 2011. Ecological and environmental footprint of 50 years of agricultural expansion in Argentina. Glob. Chang. Biol. 17, 959-973.

Volante, J.N., Mosciaro, M.J., Gavier-Pizarro, G.I., Paruelo, J.M., 2016. Agricultural expansion in the Semiarid Chaco: poorly selective contagious advance. Land Use Policy $55,154-165$.

West, T.O. Marland, G. 2002. A synthesis of carbon sequestration, carbon emissions, and net carbon flux in agriculture: comparing tillage practices in the United States. Agric. Ecosyst. Environ. 91, 217-232.

Williams, A.G., Audsley, E., Sandars, D.L., 2010. Environmental burdens of producing bread wheat, oilseed rape and potatoes in England and Wales using simulation and system modelling. Int. J. Life Cycle Assess. 15, 855-868.

Wollenberg, E., Richards, M., Smith, P., Havlík, P., Obersteiner, M., Tubiello, F.N., ... Vuuren, D.P., 2016. Reducing emissions from agriculture to meet the $2 \mathrm{C}$ target. Glob. Chang. Biol. 22, 3859-3864

Zak, M.R., Cabido, M., Cáceres, D., Díaz, S., 2008. What drives accelerated land cover change in central Argentina? Synergistic consequences of climatic, socioeconomic and technological factors. Environ. Manag. 42, 181-189. 